\title{
Morphostructural characterization of the western edge of the Huila Plateau (SW Angola), based on remote sensing techniques
}

\author{
Fernando Carlos Lopes a, b, " , Alcides José Pereira b, c, Vasco Manuel Mantas ${ }^{\mathrm{d}}$, \\ Horácio Kativa Mpengo e \\ a CITEUC, Faculdade de Ciências e Tecnologia da Universidade de Coimbra, Instituto Geofísico e Astronómico, 3000-134 Santa Clara-Coimbra, Portugal \\ ${ }^{\mathrm{b}}$ DCT, Faculdade de Ciencias e Tecnologia da Universidade de Coimbra, 3000-272 Coimbra, Portugal

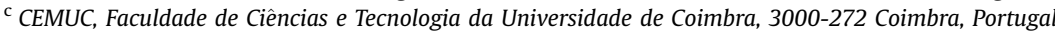 \\ ${ }^{\mathrm{d}}$ MARE - Marine and Environmental Sciences Centre, Portugal \\ e Sonangol SP, Angola
}

\section{A R T I C L E I N F O}

\section{Article history:}

Received 14 July 2015

Received in revised form

21 December 2015

Accepted 4 January 2016

Available online 6 January 2016

\section{Keywords:}

Morphostructural characterization

Remote sensing

Huila Plateau

Congo Craton

SW Angola

\begin{abstract}
A B S T R A C T
Recognition of the main morphostructural features of the western edge of the Huila Plateau (SW Angola) can be done by using remote sensing techniques associated with field work. A digital elevation model (DEM) of the area was built for this purpose. This model is based on altimeter data acquired from the Aster sensor, on which image processing techniques such as enhancement techniques, contrast change and filtering were applied. Other techniques, such as RGB colour composition, were also tested. The processed satellite images were interpreted by visual process and the results were then compared with available geological maps (scale 1: 1000 000). To facilitate both analysis and interpretation, the edge of the plateau was divided into three sectors: northern (or Chongoroi Edge), central (or Humpata Edge) and southern (or Oncocua Edge). For each sector, the main morphological aspects and main lineament systems were identified and characterized. In the specific case of the central sector, these parameters were also confirmed by field work. This study shows that the morphology of the western edge of the plateau is dominated by $\mathrm{N} 50^{\circ} \mathrm{W}-\mathrm{N} 60^{\circ} \mathrm{W}, \mathrm{N} 60^{\circ} \mathrm{E}$ and $\mathrm{N}-\mathrm{S}$ trending main tectonic systems. These results have important implications in terms of geological mapping and regional tectonics as well as in land-use planning and other areas, such as hydrogeology or geotechnics.
\end{abstract}

() 2016 Elsevier Ltd. All rights reserved.

\section{Introduction}

Satellite images obtained and analysed with the most diverse array of technological means have turned up geomorphological aspects and tectonic lineaments, which are subject to interpretation. By conducting a detailed study of relatively limited sectors of the Earth's surface, it is possible to recognize and evaluate structural aspects, particularly fracture patterns, as well as make tectono-structural and cinematic interpretations for large domains, whether they're continental (e.g., Lopes et al., 2007, 2012; Ayday and Gümüslüoglu, 2008; Baruah and Hazarika, 2008), oceanic (e.g. Pereira et al., 2008, 2009) or insular (Lopes et al., 2014). These

\footnotetext{
* Corresponding author. CITEUC, Faculdade de Ciências e Tecnologia da Universidade de Coimbra, Instituto Geofísico e Astronómico, 3000-134 Santa ClaraCoimbra, Portugal

E-mail addresses: fcarlos@dct.uc.pt (F.C. Lopes), apereira@dct.uc.pt (A.J. Pereira), vasco.mantas@dct.uc.pt (V.M. Mantas), hmpengoh@gmail.com (H.K. Mpengo).
}

new methods offer a way to bypass the high costs associated with time-consuming classic geological recognition techniques. They also enable the collection of information even in inhospitable regions and/or regions of difficult access, which are quite common in the African continent. Recognition of the main structural lineament systems of the western edge of the Huila Plateau (SW Angola) and definition of its main morphostructural characteristics to complement structural mapping are the main goals of the present study, which aims to determine such aspects through interpretation of spatial remote detection digital data acquired by the Landsat satellite's sensor (ETM+) and the Earth satellite's sensor (Aster).

\section{Geomorphological and geological settings}

\subsection{Geomorphology}

The Huila Plateau is located in the South Central region of Angola and its western edge extends from Chongoroi, Benguela 
Province, in the north $\left(13^{\circ} 34.7^{\prime} \mathrm{S}-13^{\circ} 56,6^{\prime} \mathrm{E}\right)$, to Oncocua, Cunene Province, in the south $\left(16^{\circ} 39.4^{\prime} \mathrm{S}-13^{\circ} 25^{\prime} \mathrm{E}\right)$, spanning over $300 \mathrm{~km}$. It forms the natural boundary between the provinces of Huila and Namibe (Fig. 1).

The surface of the western edge of the Huila Plateau is spread over two geomorphological units (Marques, 1977): i) unit I, the Ancient Plateau, which includes the southern half of the plateau edge and is represented by a flattened and tectonically uplifted surface; ii) unit II, the Marginal Mountain Range, which comprises the northern half of the plateau edge and is represented by very sharp reliefs. Altitude ranges from $1000 \mathrm{~m}$ (Oncocua) to $2300 \mathrm{~m}$ (Humpata Plateau). To the west, these units quickly give way to the unit III of Marques (1977), the Transition Zone, which extends parallel to the Atlantic Ocean and is represented by a succession of plateaus at different levels. This change is reflected on the landscape as an imposing step of erosion, which in certain areas is dramatic enough to result in the formation of impressive scarps (Fig. 2). Standing more than $1000 \mathrm{~m}$ high, heavily indented and, at certain points, coated with bare rock, these scarps are characterized by a strong level of fracturing, which facilitates the erosive processes and promotes rockfalls with the consequent accumulation of rock debris at the foothills. Fractures and canyons opening westwards, some deeply embedded into the wall of the massif, are quite common. The monumental Tundavala Gorge in the Humpata Plateau (e.g. Henriques et al., 2013), standing more than $2200 \mathrm{~m}$ high, is a particularly good example of such a structure (Fig. 3).

\subsection{Geology}

The western edge of the Huila Plateau is part of the Angola portion of the Proterozoic Congo Craton (the Angola-Kasai Block; e.g. Delor et al., 2008; Pedreira and Waele, 2008; Batumike et al., 2009). Its interior has remained stable since the LimpopoLiberian (c.2680 M.a to 2820 M.a) and the Eburnean and/or
Tadilian (c.2100 M.a to c.2000 M.a) orogenic cycles. However, its peripheral zones were reactivated and remobilized during the Maiombian (1300 \pm 200 M.a), Kibarin (1300 \pm 100 M.a) and PanAfrican (c. 975M.a a c. 550 M.a) orogenic cycles (e.g. Torquato et al., 1979; Carvalho, 1983; Carvalho and Alves, 1993; Ferreira da Silva, 2009).

The lithological units outcropping along the western edge have been the object of study of authors like Matias (1980), Carvalho (1983, 1984), Carvalho and Alves (1993), Carvalho et al. (2000), Pereira et al. (2011, 2013) (Fig. 4). The names and ages of these units have changed with time, due to developments in analysis techniques (geochemical and zircon $\mathrm{U} / \mathrm{Pb}$ geochronology techniques) and revision of the old classification criteria, based mainly on their field relationships and ancient $\mathrm{K} / \mathrm{Ar}$ or $\mathrm{Rb} / \mathrm{Sr}$ radiometric data. The classification presented here follows the one proposed by

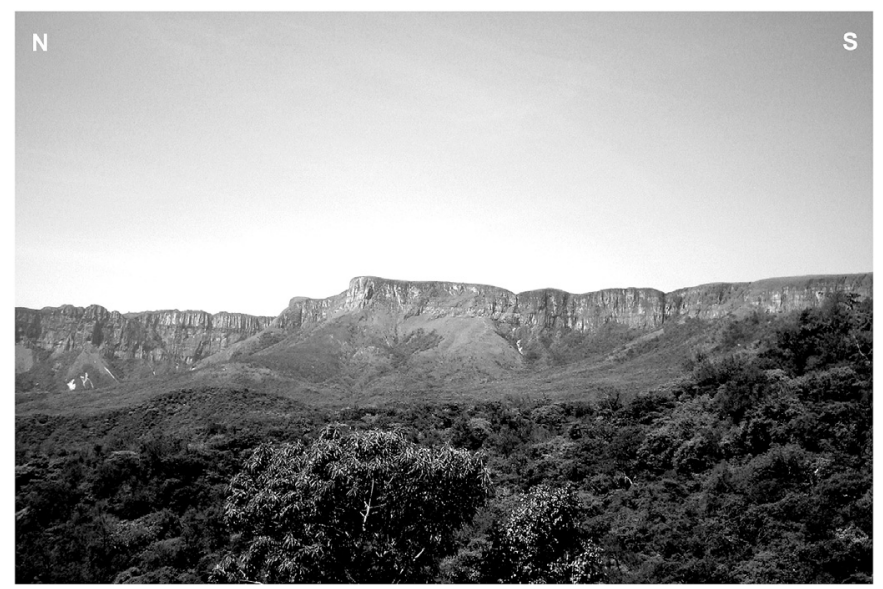

Fig. 2. The imposing scarp of the western edge of the Huila Plateau.

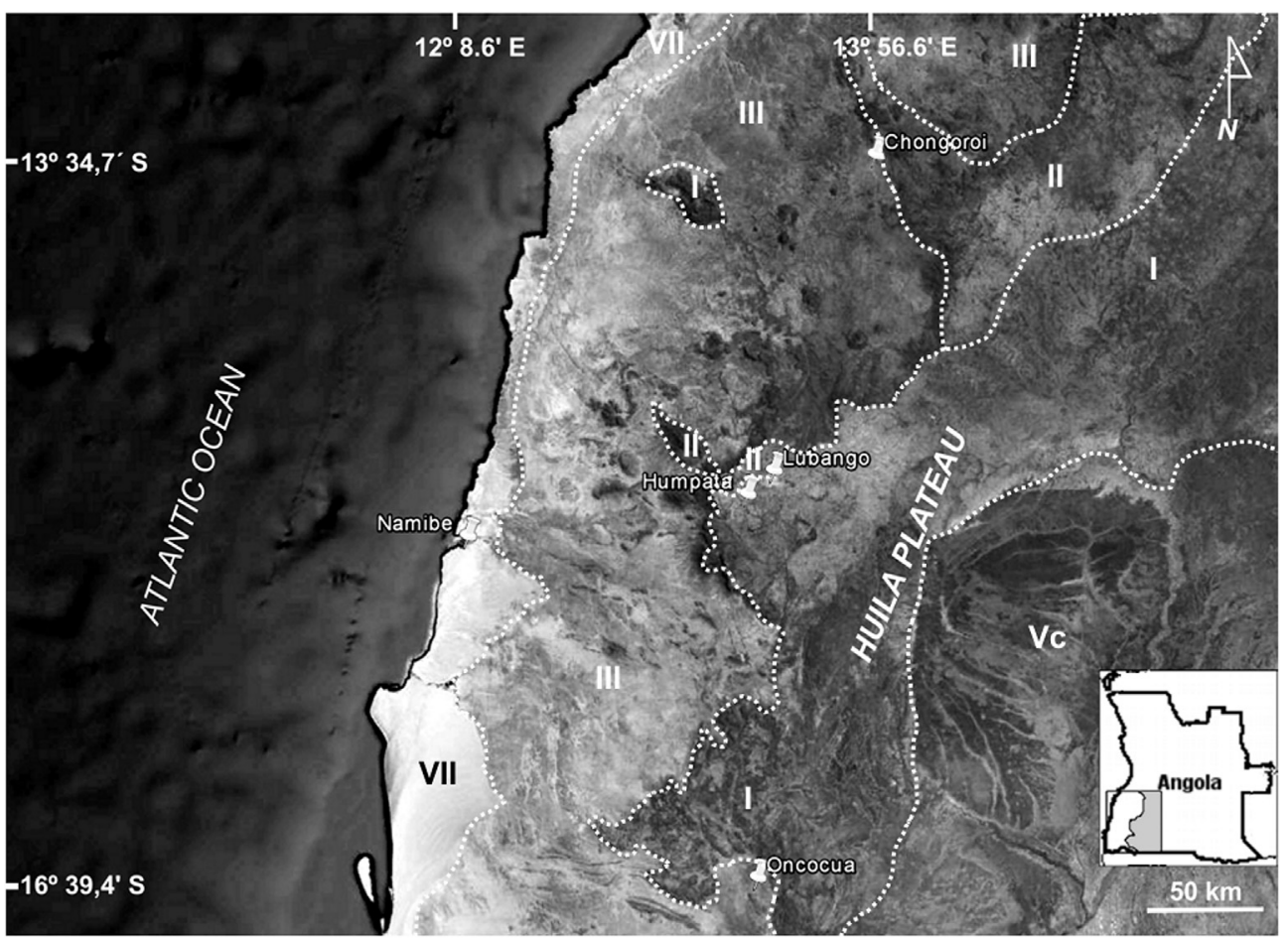

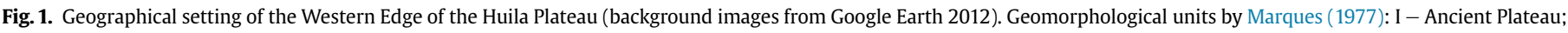
II - Marginal Mountain Range; III - Transitional Zone; Vc - Kunene river basin; VII - Coastal Zone. 
Pereira et al. (2013).

a. Kibarean distension units: they outcrop in the central sector of the western edge (Humpata Plateau), and include: i) the Chela quartzites (Chela Group; e.g. Correia, 1973, 1976; Pereira et al., 2011) and ii) the Leba Formation (e.g. Pereira et al., 2011).

b. Eburnean episode units: they outcrop mainly both in the northern and southern sectors of the western edge, and include: i) Quartz-feldspatic porphyries; ii) Eburnean granitoids and migmatits; iii) Peraluminous leucocratic granites; iv) Metaluminous granitoids; v) Gabbro-dioritic Complex.

c. Pre-Eburnean basement (remobilized at $1800 \mathrm{Ma}$ ): it outcrops in the southwestern corner of the southern sector.

This wide variety of outcropping rocks has implications in the distinct cuts of the edge of plateau.

\section{Methods}

The present work has made use of a digital elevation model (DEM) obtained from ASTER data (GDEM, obtained with NASA's LP DAAC). The DEM tiles are available at 1 -arc second spatial resolution (approximately $30-\mathrm{m}$ at the Equator), and were combined to generate a seamless mosaic of the entire study area. Techniques of analysis were applied on the model in order to highlight the structural lineaments. These techniques included the use of directional and edge detection available with ArcGIS 10 (Fig. 5).

The directional filters ("hillshade") generate a shadowed surface, which takes into account the input illumination angle and azimuth as well as the surface topography. The combination of different filters (from different illumination azimuths) it is possible to highlight the lineaments on the ground. The interpretation of the images generated by the directional filters is a visual process, that relies on the experience of a trained classifier.

Convolution filters were applied for edge detection, using a moving kernel of $3 \times 3$ pixels. Edge detection filters are often used to detect and highlight edges and can be described by matrices as follows ( $3 \times 3$ pixels Eastern Gradient):

$\begin{array}{lll}1 & 0 & 1\end{array}$

$\begin{array}{lll}2 & 0 & -2\end{array}$

$\begin{array}{lll}1 & 0 & -1\end{array}$
By running different edge detection filters, it becomes possible to create a comprehensive and multi-directional map of the main lineaments occurring in the area of interest. This information can be integrated with the directional filters for a two-tiered interpretation of the structural alignments highlighted by the methodology at the scale of the input data.

The topographical data was complemented when necessary by information provided by ASTER, Landsat 7 ETM+, and Landsat- 8 OLI, distributed by the United States Geological Survey. The common spatial resolution $(30 \mathrm{~m})$ and open data policy (Landsat and selected ASTER scenes) enabled the preparation of a comprehensive geodatabase containing multi-mission and multi-season data. The Landsat data was subjected to a simple pre-processing scheme, which included the conversion to Top-of-Atmosphere (TOA) followed by a reduction of the atmospheric effects using the "Dark Pixel" method (Chavez, 1996). Finally the data was normalized through histogram matching to streamline the comparison of adjacent scenes (Rows 69 and 70 of both path 181 and 182 of the Worldwide Reference System 2). The images were combined in large mosaics covering the entire study area.

Several band combinations were generated for visual interpretation. Furthermore, the multispectral data were used by the operators to validate the interpreted lineaments, and remove artificial features highlighted by the directional and edge detection filters (e.g. roads). The satellite imagery were segmented to enhance contrast between different regions. To this end, the border of the plateau was divided into three sectors (Fig. 5): northern (or Chongoroi Edge), central (or Humpata Edge) and southern (or Oncocua Edge). The segmentation of the images was followed by a comparison of the colour composites and pixel values with available geological maps (scale 1: 1,000,000). Photo interpretation was confirmed by field recognition, whenever possible, in several locations of the Humpata Plateau.

\section{Results}

\subsection{Chongoroi Edge}

In this sector, located between the $13^{\circ} 30^{\prime}$ and $14^{\circ} 30^{\prime} \mathrm{S}$ parallels, the plateau edge displays a general NE-SW trend and is quite indented (Fig. 6a). Its northeast end forms an arcuate spur, striking northwest, with its concavity pointing to the northeast. This sector a)

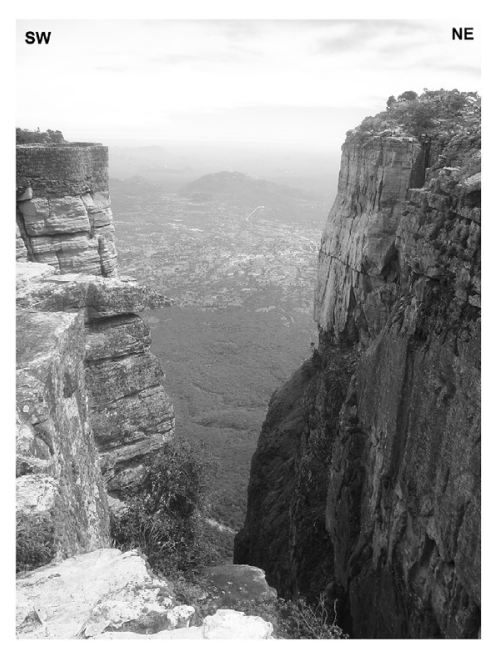

b)

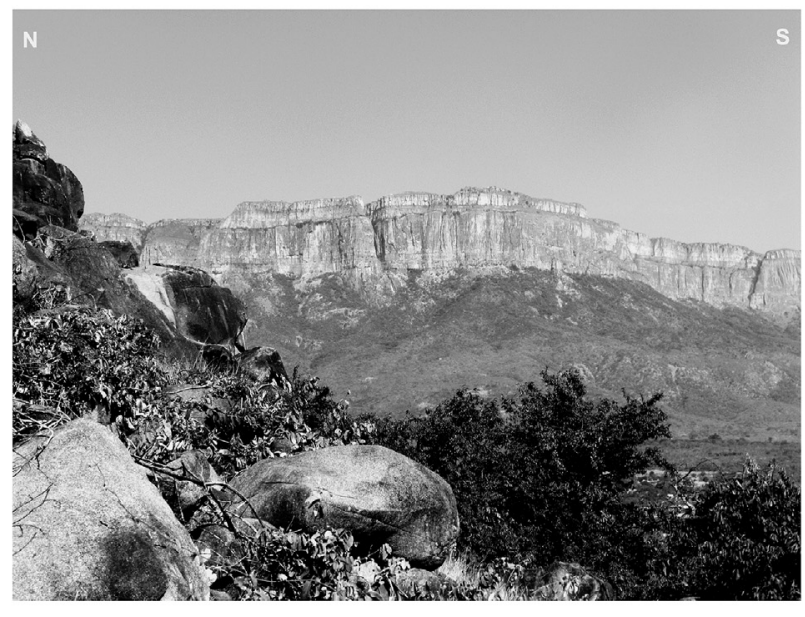

Fig. 3. The stunning Tundavala Gorge. a) View from the plateau; b) View from the town of Bibala. 


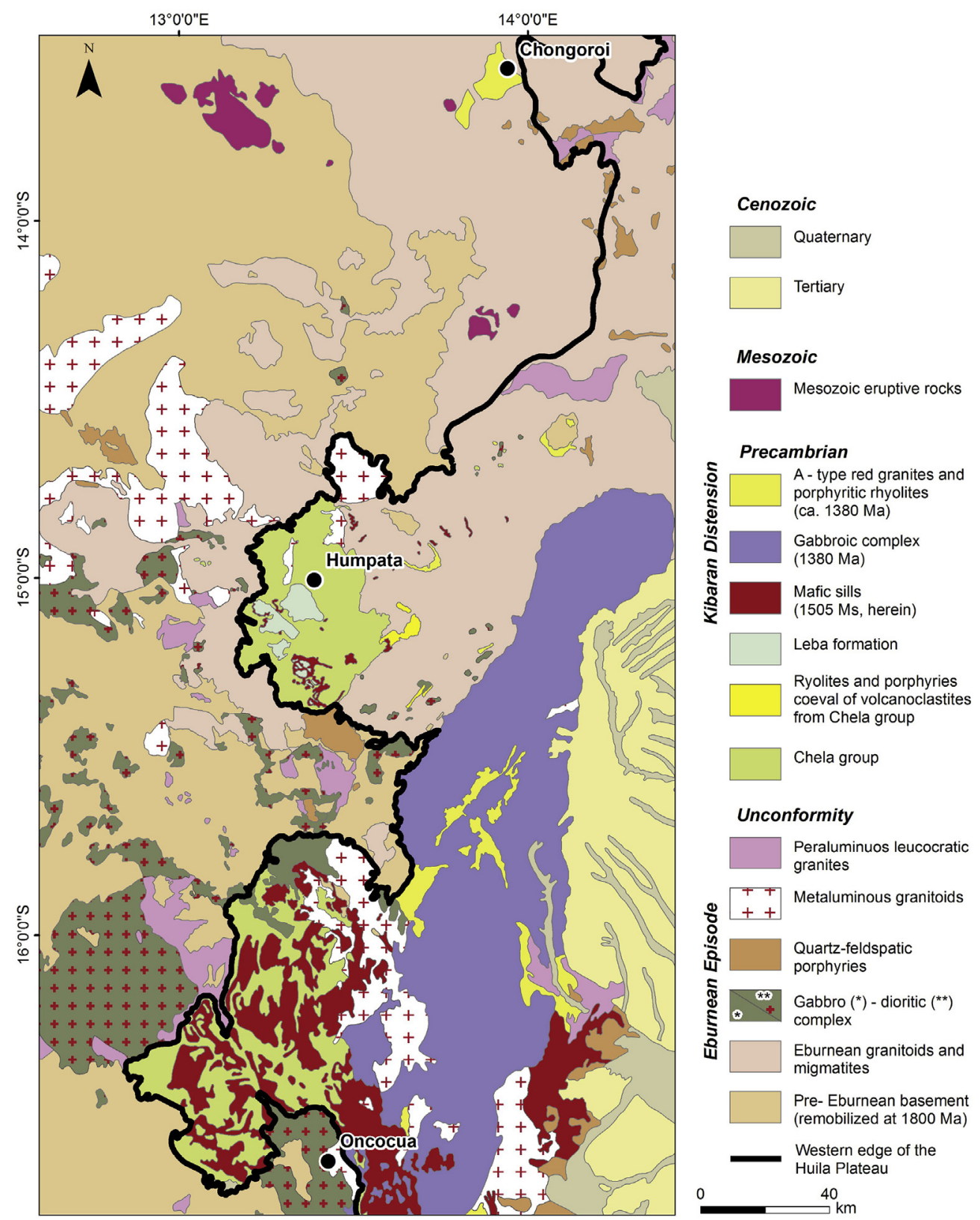

Fig. 4. Geological sketch map of the Western Edge of Huila Plateau. Redrawing from Matias, 1980, Pereira et al. (2011) and Pereira et al. (2013).

exhibits a very rugged relief in its western and north-western edges, which becomes smoother towards the southeast. This relief has a general trend of NE-SW and NNW-SSE to the east, with ridges and deep valleys in the shape of sigmoids. Next to the edge of the plateau, those trends are intersected by NW-SE striking faults.

From the morphostructural analysis that was conducted, the main systems of structural lineaments that can be interpreted are (Fig. 6a and b):

- $\mathrm{N} 45^{\circ} \mathrm{W}-\mathrm{N} 60^{\circ} \mathrm{W}$ : the predominant and most penetrative system in this sector, it is more evident along the edge of the plateau, cutting it into facets with the same orientation.

- $\mathrm{N} 60^{\circ} \mathrm{W}-\mathrm{N} 70^{\circ} \mathrm{W}$ : mainly identified in the central and northeastern regions of the edge, where it controls the strike and the sigmoid shape of the relief.
- N-S to NNW-SSE: mainly identified in the central and northeastern regions of the edge.

It is also worth highlighting the $\mathrm{E}-\mathrm{W}$ to $\mathrm{N} 30^{\circ} \mathrm{W}$ trending arcuate lineaments in this sector. This very penetrative system is responsible for the spur shape of the north-eastern end of the edge of the plateau.

\subsection{Humpata Edge}

This sector is located between the $14^{\circ} 30^{\prime} \mathrm{S}$ and $15^{\circ} 30^{\prime} \mathrm{S}$ parallels and it is home to the Lubango city, which stands at an altitude of around $1900 \mathrm{~m}$. Here, the edge of the plateau has a semi-elliptical shape, with its convexity facing west and its major axis striking NESW. It has very rugged facets alternating between NW-SE and NE- 


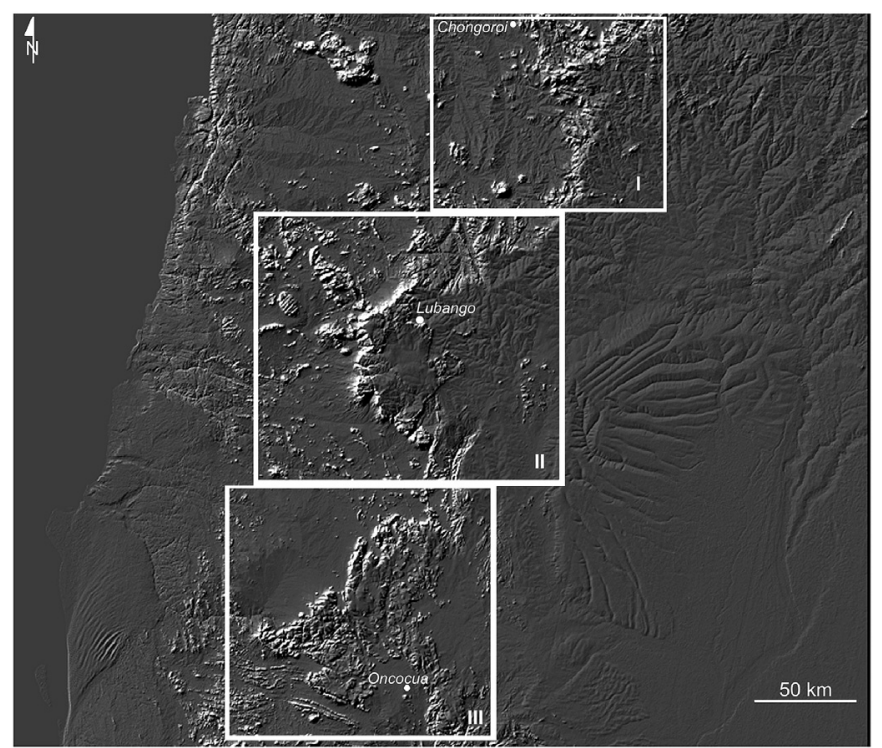

Fig. 5. Digital terrain model (DEM) of the Huila Plateau obtained from ASTER data (GDEM, obtained with NASA's LP DAAC), with a NW directional filter applied. The topographical data was complemented by information provided by the Landsat-7 ETM + . The sectors under study are represented by rectangles outlined in white: I Northern sector (Chongoroi Edge); II - Central sector (Humpata Edge); III - Southern sector (Oncocua Edge).

SW orientations (Fig. 7a). They form small polygons in the west and south-west, whereas to the northeast their appearance is dendriform. Its relief is higher and more flattened in the midwestern region (Humpata Plateau) than in the north-eastern and southwestern ends. Here, the relief is more rugged but relatively lower in altitude. It becomes lower and smoother to the east and southeast. To the northeast, the relief seems at times to be conditioned by NE-SW and NW-SE trending fault corridors, where S-sigmoidshaped deep valleys and Z-sigmoid-shaped ridges are arranged in échelon.

It can be inferred, from morphostructural analysis, that the dominant lineament systems in this sector are the same as those in the northern sector (Fig. 7a and b). On-field observations carried out in several locations of the Humpata Plateau confirm this interpretation.

- NW-SE (N50 $\left.{ }^{\circ} \mathrm{W}-\mathrm{N} 60^{\circ} \mathrm{W}\right)$ : the most penetrative and most prevalent system in this sector, it cuts the edge of the Humpata Plateau originating rugged facets with the same trend. It is represented by deep canyons and fractures, of which the Tundavala Gorge, located northwest of the Lubango city, is the most representative example (Figs. 3 and 7). The highest altitudes registered in the Huila edge $(2326-233 \mathrm{~m})$ are close to the Tundavala site. On the slopes of the Leba Road (Fig. 8) and the Tundavala-Lubango Road (Fig. 9) there are granitic rocks deeply affected by brittle and ductile shear zones with this trend. On the slopes of the Leba Road, some granites are affected by $\mathrm{N} 50^{\circ} \mathrm{W} ; 22^{\circ} \mathrm{S}$ trending shear zones, which are intruded by dolerite dykes (Fig. 10). On the other hand, one of the joint systems that is predominant in several quartzite outcrops (Chela Group) close to the Humpata town (Fig. 11) and the Tundavala Gorge (Fig. 12) also strikes in this direction. This lineament system extends to the northwest, through the Namibe peneplain to the coast. Many of them are intruded by dolerite dykes

a)

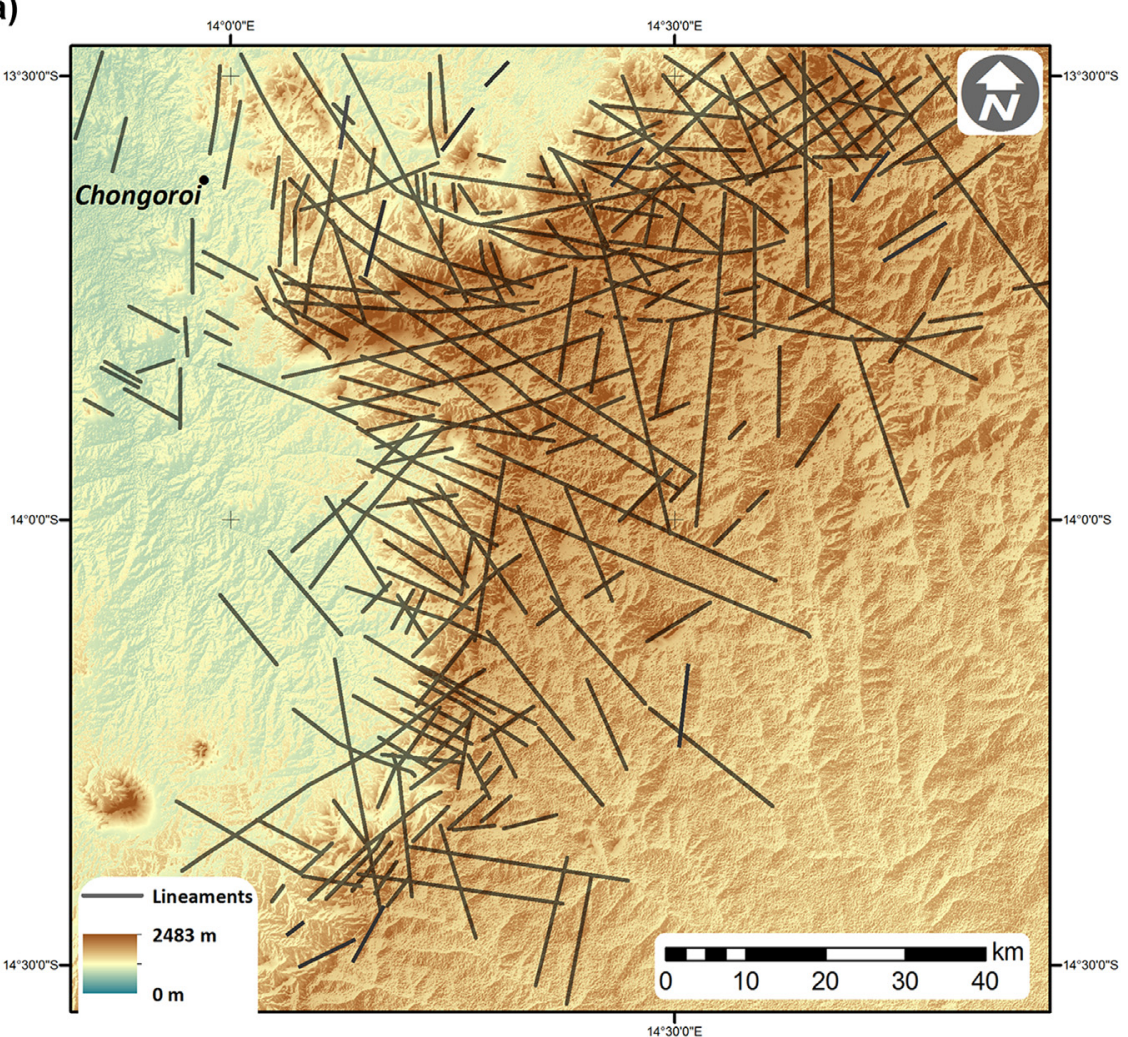

b)

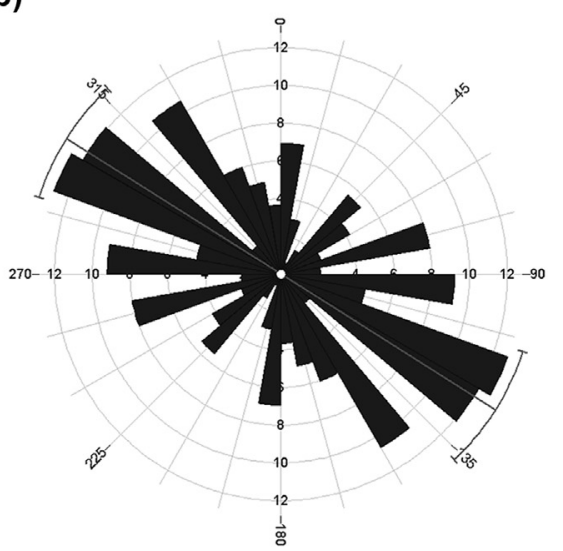

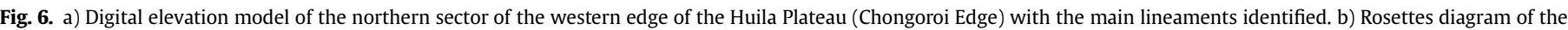
northern sector of the western edge of the Huila Plateau showing the orientation of the predominant structural lineaments. 
a)

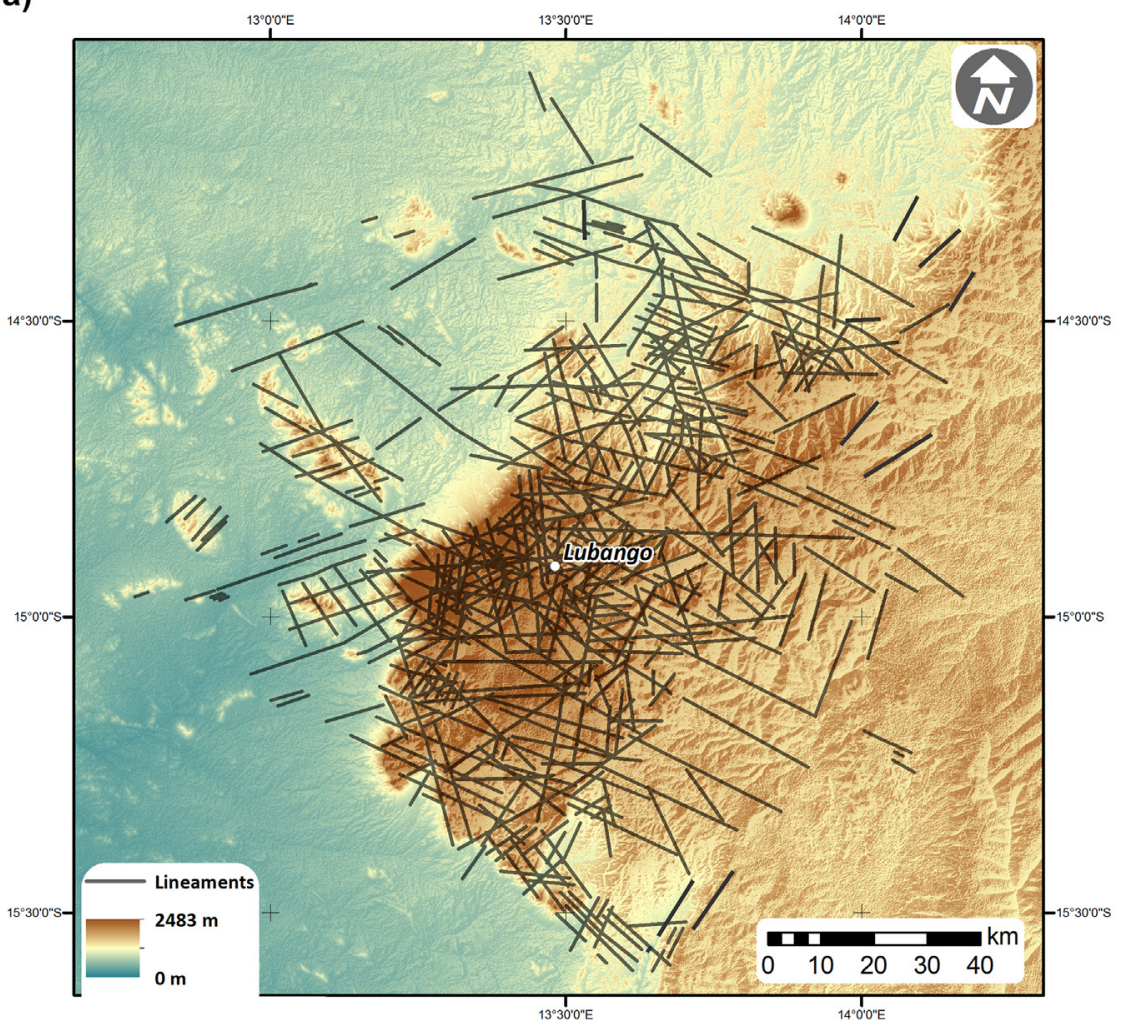

b)

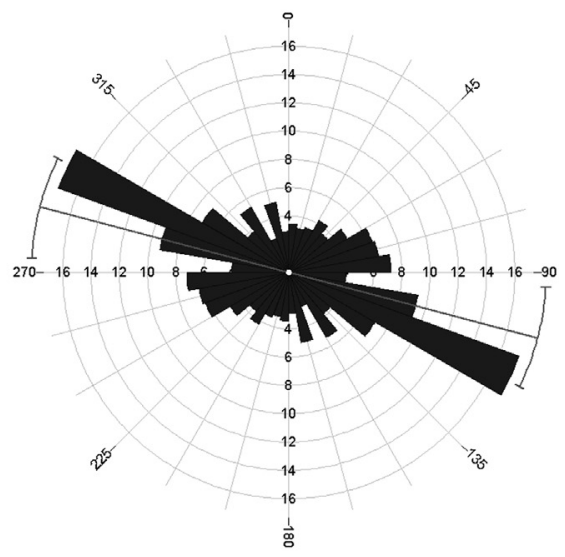

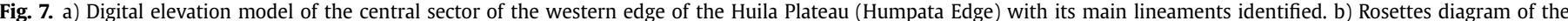
central sector of the western edge of the Huila Plateau (Humpata Edge) showing the orientation of the predominant structural lineaments.

forming elongated ridges with the same trend as the ones that outcrop next to the Bibala town.

- NE-SW to ENE-WSW: the second most common lineament system in this sector, it can be identified mainly in the centre and north-eastern regions of the edge of the Humpata Plateau, forming corridors that extend to the adjacent peneplain and controlling the sigmoid shape of the NW-SE striking dolerite ridges. On the Leba and the Lubango-Tundavala roads' slopes, cataclastic deformation zones with this strike can be identified in granites. On the Leba Road it is possible to identify, in the quartzites of the Chela Group, a fault-propagation fold striking in this direction (Fig. 13). Joints striking in this direction can also be identified in several quartzite outcrops next to the Humpata town (Fig. 11) and the Tundavala Gorge (Fig. 12).

- N-S to NNW-SSE: this system is mainly identified in the Humpata Plateau and in the north-eastern end of this sector. It seems to favour the implantation of dolerite dykes.

The NNE-SSW and E-W systems are less significant and can be identified throughout the whole edge. a)

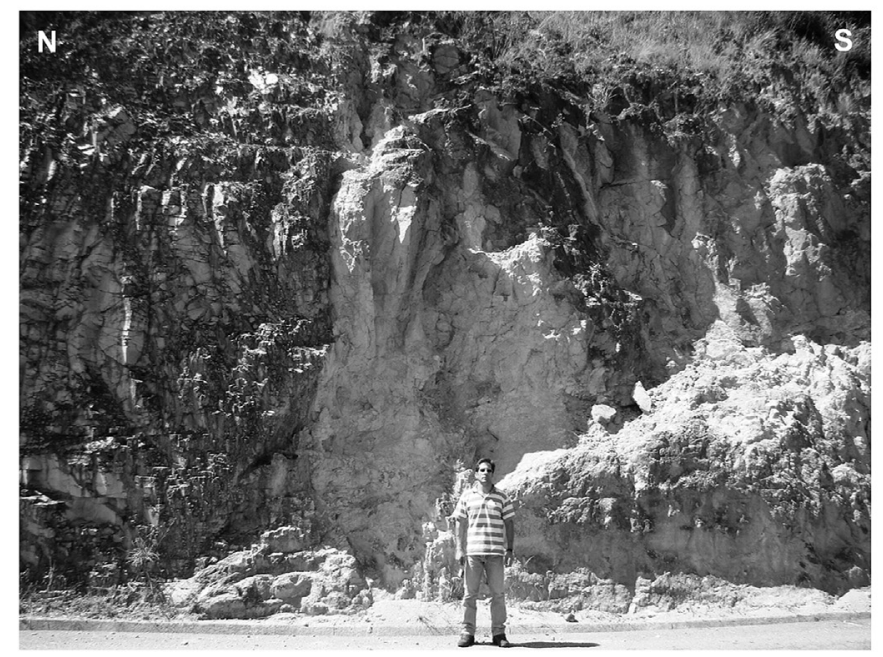

b)

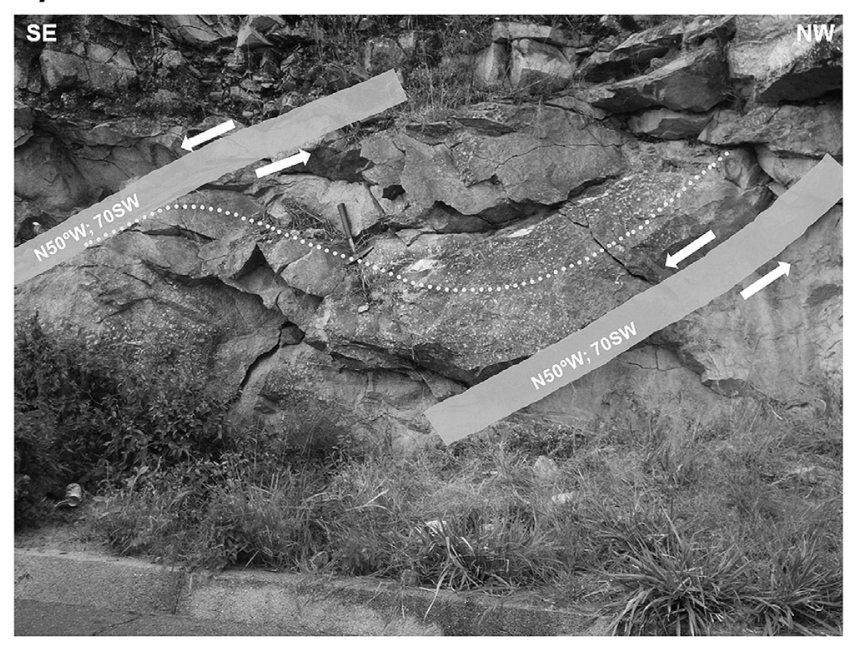

Fig. 8. Leba Road: a) Brittle shear zone in granite; b) ductile shear zone in granite. 


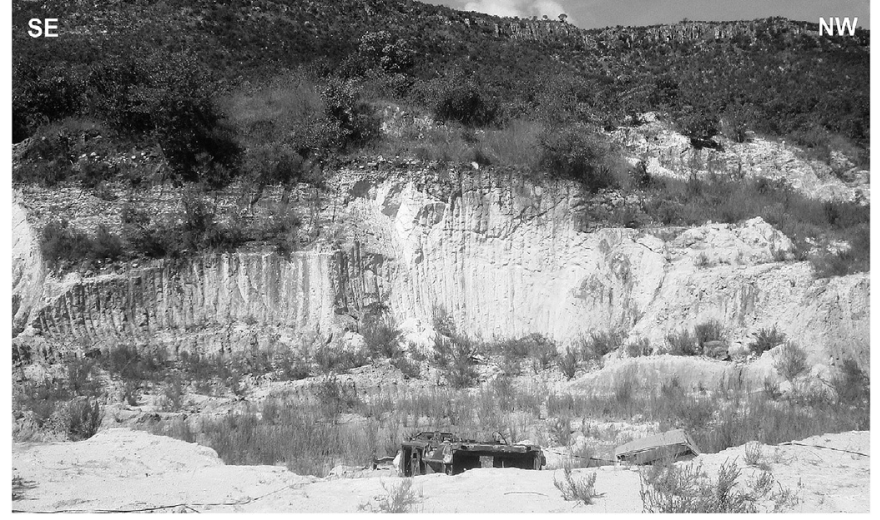

Fig. 9. Lubango-Tundavala Road: Brittle shear zone in granite.

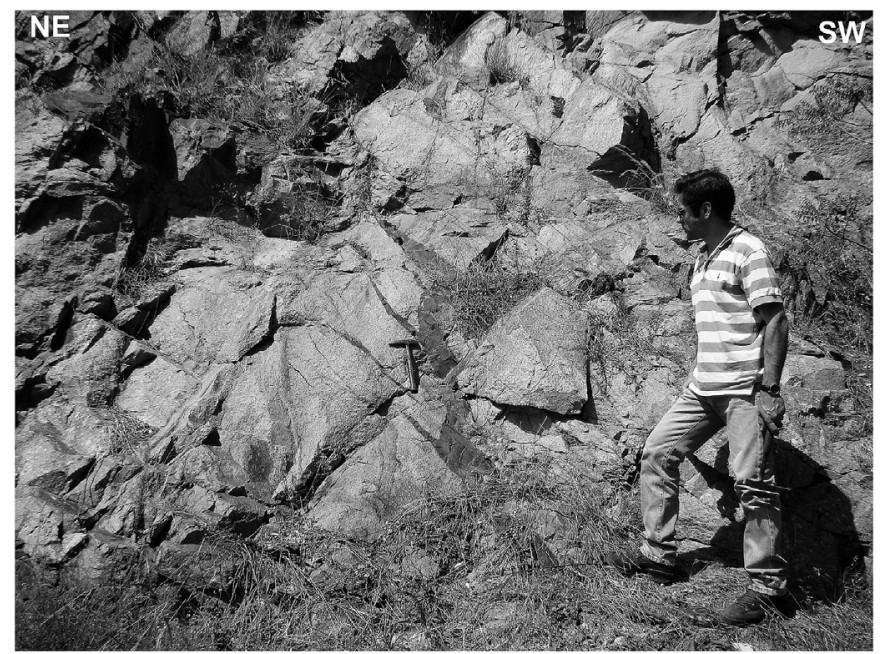

Fig. 10. Granites affected by $\mathrm{N} 50^{\circ} \mathrm{W} ; 22^{\circ} \mathrm{S}$ trending shear zones intruded by dolerite dykes.

\subsection{Oncocua edge}

This sector is located between the $15^{\circ} 30^{\prime} \mathrm{S}$ and $16^{\circ} 45^{\prime} \mathrm{S}$ parallels. Here, the plateau's edge exhibits two orthogonally arranged faces (Fig. 14a). The longest, facing northwest (north-western face),

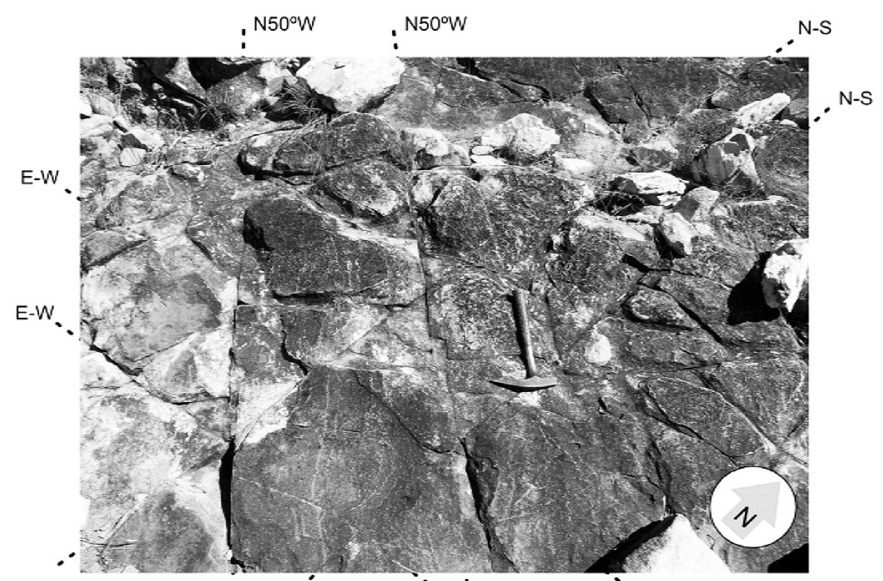

Fig. 11. Systems of fractures affecting a quartzite outcrop located on the Humpata Plateau.

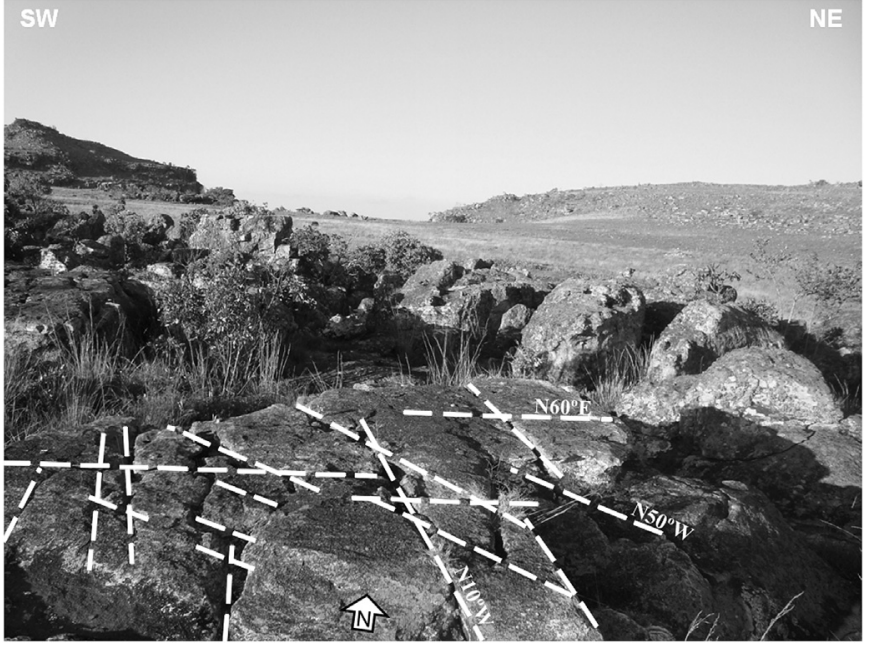

Fig. 12. Systems of fractures affecting a quartzite outcrop located on the Tundavala area.

is NE-SW striking and follows the Chabiva Mountain Range. The shortest faces southwest (south-western face) and is NW-SE trending. Its vertex intersects the Muvelaumo Mountain Range, which is parallel to the south-western face and has an altitude of around $1690 \mathrm{~m}$. In both faces, the edge is quite jagged, which has implications on the ground itself, much like what happens in the other sectors. Thus, the land is at times remarkably rich in fractures, canyons and crevices, which are sometimes quite incisive and open onto the empty valley to the west and southwest. Relief is rougher here than in the Humpata sector, but the average altitude of this sector is less than that of the Humpata sector (about $1500 \mathrm{~m}$ ). The lowest altitudes (around $1000 \mathrm{~m}$ ) can be identified in the southeastern end of the shortest face, in the Oncocua region.

Morphostructural analysis allowed the identification of the following main lineament systems (Fig. 14a and b):

- NW-SE (N50 $\left.{ }^{\circ} \mathrm{W}-\mathrm{N} 60^{\circ} \mathrm{W}\right)$ : much like the previous sectors, it is the most penetrative and most prevalent system, hacking the north-western face of the border into canyons and fractures and controlling the orientation of the south-western face.

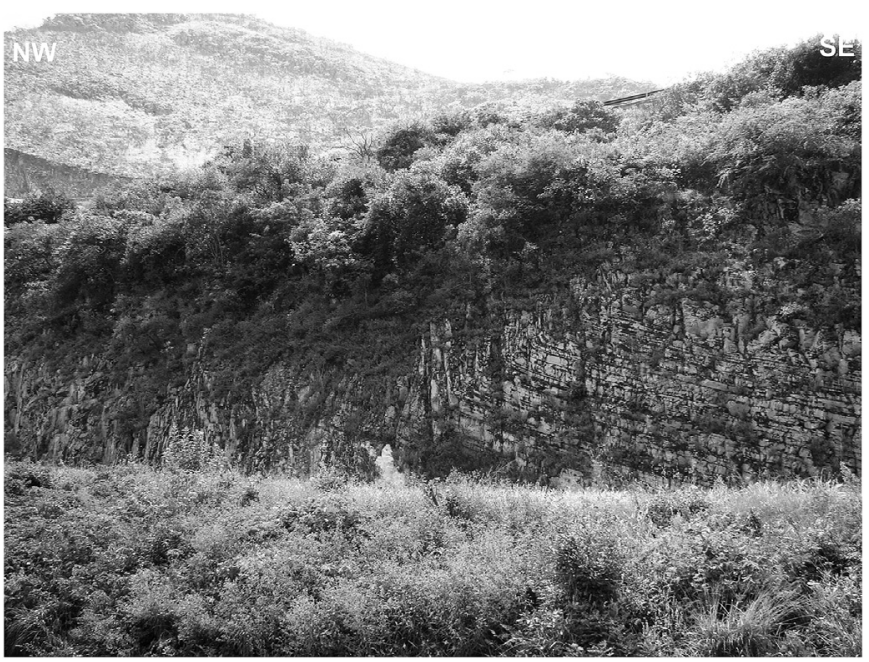

Fig. 13. Leba Road. Quartzites of the Chela Group affected by brittle-ductile zone (faultpropagation fold) 

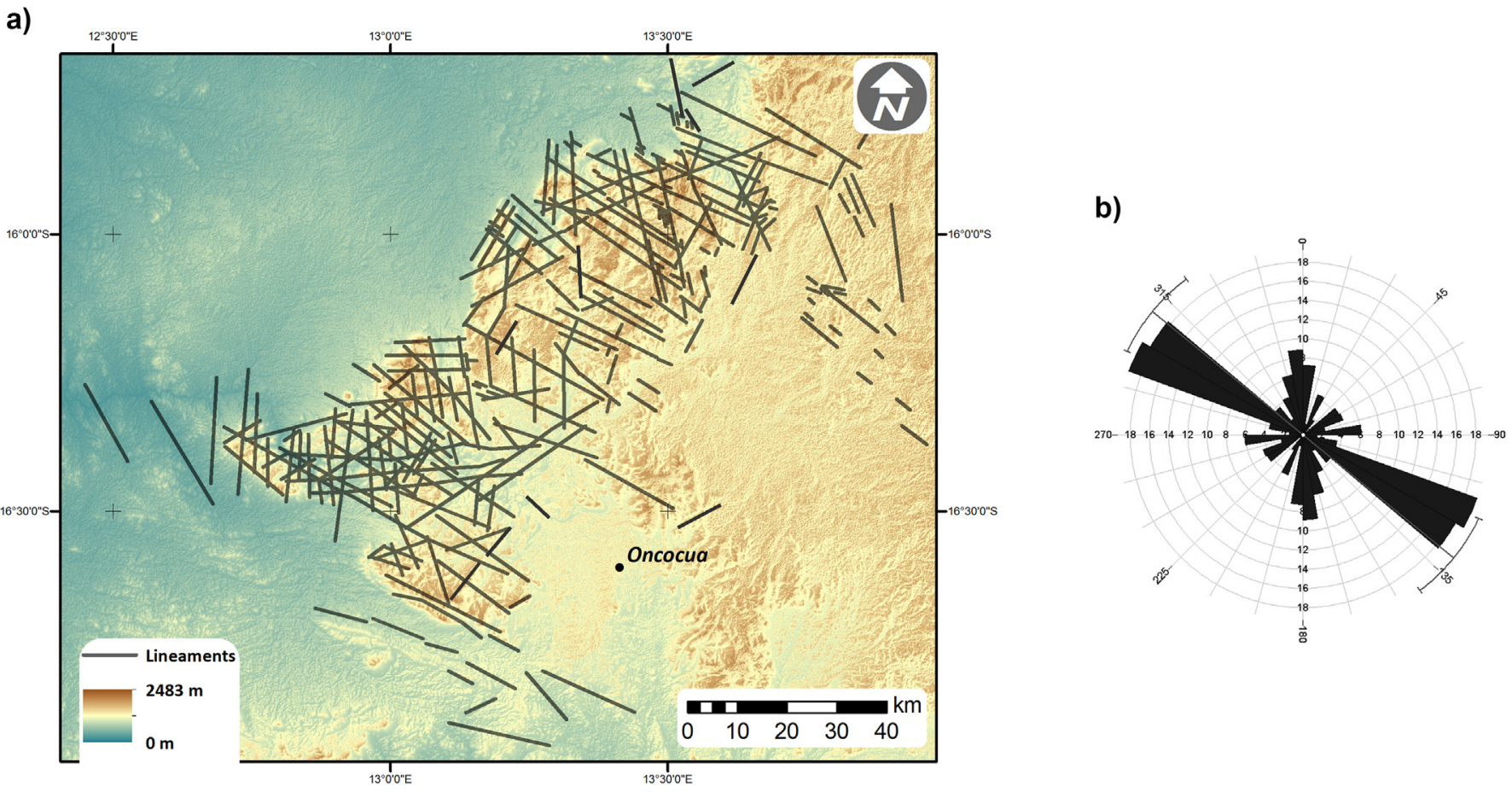

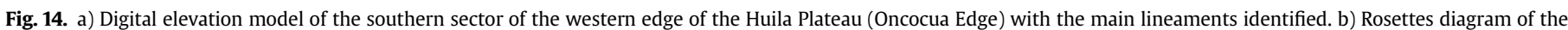
southern sector of the western edge of the Huila Plateau (Oncocua Edge) showing the orientation of the predominant structural lineaments.

- N-S to NNW-SSE: the second most predominant system in this sector.

- NE-SW: this system controls the orientation of the northwestern face of the Oncocua edge and carves its southwestern face. Although it is too a penetrative system, it isn't as prevalent as in the other sectors.

- E-W: this system is mainly identified in the intersection zone of the two faces of the plateau.

- ENE-WSW: this system obliquely intersects the previous systems and it can be identified mainly in the north-eastern region of the northwest face of the Oncocua Edge.

\section{Discussion}

The western edge of the Huila Plateau is an approximately N-S striking rocky wall of over $300 \mathrm{~km}$ in length. The tectono-structural analysis conducted on this morphostructure (through the interpretation of digital data obtained from spatial remote sensing techniques coupled with field observations) allowed the identification of its various intersecting lineament systems. These lineament systems manifest themselves on the field as fractures and

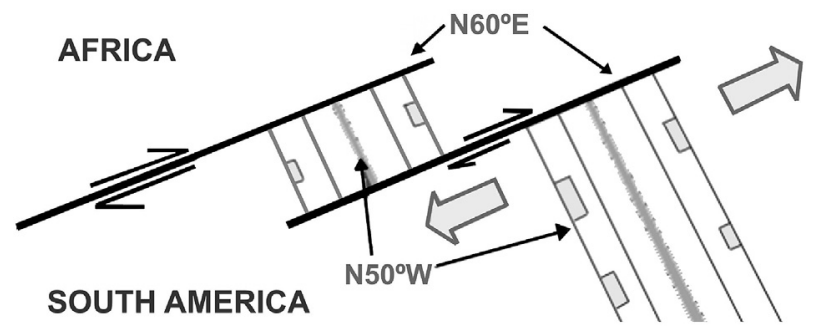

Fig. 15. Schematic model for the operation of $\mathrm{N} 60^{\circ} \mathrm{E}$ and $\mathrm{N} 50^{\circ} \mathrm{W}$ structural systems during the rift phases of lower Cretaceous. rather incisive canyons, opening westward onto the emptiness of the Namib peneplain.

- $\mathrm{N} 50^{\circ} \mathrm{W}-\mathrm{N} 60^{\circ} \mathrm{W}$ : this is the most penetrative and most dominant system along the western edge of the plateau. It cuts the edges into rugged facets with the same orientation, and it manifests itself on the field in the shape of fractures and canyons. These lineaments form structural corridors that extend to the northwest through the Namibe peneplain as deep faults or shear zones, through which doleritic rocks have at times intruded. The faults in this system, which were thrust frontal ramps of the Proterozoic orogenic belts, would have acted as normal faults during the aptian rift phase of the South Atlantic (Fig. 15) (Hudec and Jackson, 2004), which led to the fragmentation of the Gondwana Angola-Kasai Block.

- $\mathrm{N} 60^{\circ} \mathrm{E}$ : this is the second most predominant system. In the central sector it presents itself as shear surfaces that extend to the southwest, through the Namibe peneplain, where they control the orientation and the sigmoid shape of the NW-SE striking doleritic ridges. This system is comprised of deep faults, old regional shear zones and lateral ramps of the Proterozoic orogenic belts, which would have acted as transfer fault zones (Fig. 15) during the aptian rift phase of the South Atlantic and currently extend offshore as transform faults (Hudec and Jackson, 2004; Versfelt, 2010). In certain places, they seem to promote intrusion of doleritic dykes.

- N-S: this system can be identified in the central and northeastern regions of the edge of the Huila Plateau, where it controls the orientation of the relief. In some areas, N-S striking lineaments are intruded by sills and doleritic dykes.

- $\mathrm{N} 10^{\circ} \mathrm{W}-\mathrm{N} 20^{\circ} \mathrm{W}$ : mainly identified in the central and southwestern regions of the plateau edge, it controls the orientation of the relief. In some areas, lineaments with this direction are intruded by sills and doleritic dykes. 
The $\mathrm{N} 20^{\circ} \mathrm{E}$ and $\mathrm{E}-\mathrm{W}$ systems aren't as common, but can be identified all across the edge and may have a local impact in the geomorphology of the region. On its north-eastern end, the E-W to $\mathrm{N} 30^{\circ} \mathrm{W}$ lineament system is quite penetrative and it is responsible for the spur shape of the plateau edge. It is part of the Pan-african orogenic belt that occurs in the margins of the Congo Craton (e.g. Maurirv, 1993). In the south-western extremity, the ENE-WSW system is worth mentioning, as it obliquely intersects the previous systems.

The $\mathrm{N} 50^{\circ} \mathrm{W}-\mathrm{N} 60^{\circ} \mathrm{W}$ and $\mathrm{N} 60^{\circ} \mathrm{E}$ systems, heritage of the pre-rift cratonic bedrock, are responsible for the main morphostructural characteristics of the western edge of the Huila Plateau. They control the irregular contour of its scarp that stand as rugged facets alternating between NW-SE and NE-SW orientations. The relief of the interior of the plateau is itself dependent on these two structural directions. Sigmoid-shaped deep valleys (in shape of an "S") and ridges (in shape of a "Z") are arranged in échelon. The combination of the structural lineaments with the digital terrain model and the geology of the region highlights the importance of the main structural systems in the complex tectonic evolution of the region, as they act as true deformation corridors. The occurrence of doleritic dykes and sills along some of the lineament of these systems proves that the correspondent faults are very deep-rooted, reaching the lower crust.

\section{Conclusions}

The present study has highlighted morphological aspects of the western edge of the Huila Plateau and allowed the identification and characterization of the several structural lineament systems that intersect each other in the plateau and are responsible for the appearance of fractures/faults, crevices and canyons on the field. The results of this work have important implications in terms of geological mapping and regional tectonic interpretations, as well as regional planning policies. The main contributions this study can offer include: $i$ ) contribution to regional mapping and tectonicstructural interpretations: this study allows assessment and complementation of current regional geological mapping, particularly in regards to the fracture pattern of the western edge of the Huila Plateau. The large systems of pre-rift structural lineaments $\left(\mathrm{N} 50^{\circ} \mathrm{W}-\mathrm{N} 60^{\circ} \mathrm{W}, \mathrm{N}-\mathrm{S}, \mathrm{N} 60^{\circ} \mathrm{E}\right)$ become more evident; likewise highlighted are other secondary directions $\left(\mathrm{N} 10^{\circ} \mathrm{W}-20^{\circ} \mathrm{W} ; \mathrm{N} 20^{\circ} \mathrm{E}\right.$; $\mathrm{E}-\mathrm{W})$. This is a valuable asset to regional tectonic and structural interpretations. The importance of the $\mathrm{N} 60^{\circ} \mathrm{E}$ and $\mathrm{N} 50^{\circ} \mathrm{W}-\mathrm{N} 60^{\circ} \mathrm{W}$ lineaments is evidenced, because they acted as transfer faults and normal faults (respectively) during the rift phase of the lower Cretaceous, and so they are responsible for the indented profile of the western edge of the Huila Plateau; $i i)$ contribution to the field of hydrogeology: the fracture pattern influences the drainage system (dendritic to rectangular) and the location of the recharge zones of the aquifers that are present in the Huila Plateau. The information gathered by this system is important in establishing the protection perimeter of the recharge zones; iii) contribution to slope stability: the road networks linking the plateau to the lowlands cross the edge of the plateau. The slope stability depends not only on the dip, but also on the degree of fracturing and alteration of its constituent rocks, as well as climatic conditions. Landslides are common, particularly rockfalls, which leads to disruption of road communication. Similarly, along a few slopes, close to the scarps, where vegetation is scarce, it is quite common to find small villages whose inhabitants live under threat of landslides. Knowing the fracture pattern could therefore help to minimize the risks associated with these phenomena.

\section{Acknowledgements}

This research is co-funded by FCT, the Portuguese Science Foundation, under the contract of the UID/Multi/00611/2013 research project and COMPETE Programme. We would like to thank the Instituto Superior Politécnico da Tundavala, Huíla, Angola, for helping us in the logistic and subsistence arrangements for the field seasons. We are grateful to Liliana Freitas for redrawing the geological map and to M. T. Barata for reviewing an early version of this work. Two anonymous reviewers made helpful comments and suggestions at a later stage.

\section{References}

Ayday, C., Gümüslüoglu, E., 2008. Detection and interpretation of geological linear features on the satelite images by using gradient filtering and principal component analysis. Int. Achives Photogramm. Remote Sens. Spacial Inf. Sci. XXXVII (B8), 1207-1210. Beijing.

Baruah, S., Hazarika, D., 2008. A GIS based tectonic map of northeastern India. Curr. Sci. 95, 176-177.

Batumike, J.M., Griffin, W.L., O'Reilly, S.Y., Belousova, E.A., Pawlitschek, M., 2009. Crustal evolution in the central Congo-Kasai Craton, Luebo, D.R. Congo: Insights from zircon $\mathrm{U}-\mathrm{Pb}$ ages, Hf-isotope and trace-element data. Precambrian Res. 170, 107-115.

Carvalho, H., 1983. Notice explicative préliminaire sur la géologie d'Angola. Inst. Investig. Trop. Sér. Géol. Lisb. 6, 15-30.

Carvalho, H., 1984. Estratigrafia do Precâmbrico de Angola. Garcia Orta, Lisb. 7, 1-66. Carvalho, H., Alves, P., 1993. The Precambrian of SW Angola and NW Namibia. Comunicações do Instituto de Investigação Científica Tropical, Série Ciências da Terra $n^{\circ} 4$.

Carvalho, H., Tassinari, C., Alves, P., Guimarães, F., Simões, M., 2000. Geochronological review of the Precambrian in Western Angola: links with Brazil. J. Afr. Earth Sci. 31, 383-402.

Chavez Jr., P.S., 1996. Image-based atmospheric corrections - Revisited and Improved. Photogramm. Eng. Remote Sens. 62, 1025-1036.

Correia, H., 1973. Sobre a existência de rochas vulcanoclásticas na Formação da Chela (Região do Planalto da Humpata). Ciênc. Geol. Cursos Ciênc. Univ. Luanda 1, 27-32.

Correia, H., 1976. O Grupo da Chela e Formação da Leba como novas unidades litoestratigráficas resultantes da redefinição da Formação da Chela na região do Planalto da Humpata (Sudoeste de Angola). Bol. Soc. Geol. Port. 20, 65-130.

Delor, C., Theveniaut, H., Cage, M., Pato, D., Lafon, J.-M., Bialkowski, A., Rooig, J.-Y. Neto, A., Cavongo, M., Sergeev, S., 2008. New insights into the Precambrian geology of Angola: basis for an updated lithochronological framework at 1 : 2000000 scale. In: 22nd Colloquium of African Geology. Hammamet -Tunisia, pp. 52-53.

Ferreira da Silva, A., 2009. A geologia da República de Angola desde o Paleoarcaico ao Paleozóico Inferior. Bol. Minas 44, 99-162.

Henriques, M.H., Tavares, A.O., Bala, A.L.M., 2013. The Geological Heritage of Tundavala (Angola): and integrated approach of characterization. J. Afr. Earth Sci 88, $62-71$.

Hudec, M.R., Jackson, M.P.A., 2004. Regional restoration across the Kuanza Basin, Angola: salt tectonics triggered by repeated uplift of metastable passive margin. AAPG Bull. 88, 971-990.

Lopes, F.C., Pereira, A., Vicente, A., 2007. Recognizing salt-structures on the basis of geophysical and remote sensing data: the case of Monte Real salt-structure (onshore West-Central Portugal). In: Proceedings Book. IEEE, International Geoscience and Remote Sensing Symposium, July Barcelona, Spain, pp. 23-27.

Lopes, F.C., Pereira, A., Mantas, V., 2012. Mapping of salt structures and related fault lineaments based on remote sensing and gravimetric data: the case of Monte Real salt-wall (onshore West-Central Portugal). AAPG Bull. 96 (4), 615-634. http://dx.doi.org/10.1306/08101111033.

Lopes, F.C., Caselli, A.T., Machado, A., Barata, M.T., 2014. The development of the Deception Island volcano caldera under control of the Bransfield Basin sinistra strike-slip tectonic regime (NW Antarctica). In: Platz, T., Massironi, M., Byrne, P.K., Hiesinger, H. (Eds.), Volcanism and Tectonism across the Inner Solar System. Geological Society, London. Special Publications, 401. http://dx.doi.org/ 10.1144/SP401.6.

Marques, M.M., 1977. Esboço das unidades geomorfológicas de Angola (2a aproximação). Inst. Inv. Cient. Trop. Garcia Orta, Sérv. Geol., Lisb. 2, 41-43.

Matias, D.N., 1980. Carta Geológica de Angola à escala 1:1000000 (folha 3). Instituto Geográfico Cadastral.

Maurirv, J.C., 1993. The Pan-African west-Congo belt: links with eastern Brazil and geodynamical reconstruction. Int. Geol. Rev. 35, 436-452.

Pedreira, A.J., Waele, B., 2008. Contemporaneous Evolution of the Palaeoproterozoic-mesoproterozoic Sedimentary Basins of the São Francisco-Congo Craton. Geological Society, London, pp. 33-48. Special Publications, 294.

Pereira, L.C., Andrade, A.A.S., Gomes, C.R., Lopes, F.C., Azevedo, J.M., 2008. Análise Geométrica e cinemática de alinhamentos tectónicos no Atlântico nordeste. Comun. Geol. 95, 51-59. 
Pereira, L.C., Lopes, F.C., Gomes, C.R., 2009. Alinhamentos tectono-estruturais na Margem Sudoeste Ibérica - um modelo interpretativo. In: Livro de resumos. 6 Simpósio sobre a Margem Ibérica Atlântica. Oviedo. 1-5 Dezembro, pp. 25-28.

Pereira, E., Tassinari, C.C.G., Pereira, E., Rodrigues, J.F., Van-Dúnem, M.V., 2011. New data on the deposition age of the volcano-sedimentary Chela Group and its Eburnean basement: implications to post-Eburnean crustal evolution of the SW of Angola. Comun. Geol. 98, 29-40.

Pereira, E., Rodrigues, J., Van Dúnem, M.V., 2013. Carta Geológica de Angola, à escala
1:250 000: Folha Sul D-33/T (Chibia). Publicação do Instituto Geológico de Angola.

Torquato, J., Silva, A., Cordani, U., Kawashita, K., 1979. Evolução Geológica do Cinturão Móvel do Quipungo no Ocidente de Angola. Acad. Bras. Ciências 51, 133-144.

Versfelt, J.W., 2010. South Atlantic margin rift Basin asymmetry and implications for pre-salt exploration. In: Proceeding Book. AAPG International Conference and Exhibition, Rio de Janeiro, Brazil, November 15-18, 2010. 